\title{
Formulary Management of the Protease Inhibitors Boceprevir and Telaprevir for Chronic Hepatitis C Virus
}

\author{
Alexandra Tungol, PharmD; Kellie Rademacher, PharmD; and Jeremy A. Schafer, PharmD, MBA
}

\begin{abstract}
BACKGROUND: Hepatitis $\mathrm{C}$ virus (HCV) is the most common chronic bloodborne illness in the United States. The incidence of acute hepatitis $C$ in the United States peaked near 50,000 cases in the late 1980 s but has stabilized since 2003 to less than 5,000 cases annually. The combination of pegylated interferon (peginterferon) and ribavirin has been the standard recommended treatment for HCV. Protease inhibitors telaprevir and boceprevir were approved by the FDA in May 2011 for the treatment of hepatitis $C$ genotype 1 in combination with peginterferon and ribavirin.
\end{abstract}

OBJECTIVE: To review the phase 3 trials for telaprevir and boceprevir and provide managed care considerations.

METHODS: A MEDLINE review was performed for articles published and available through September 15, 2011, using keywords "boceprevir" or "telaprevir" with an emphasis on phase 3 trials. The literature search was limited to articles in English, clinical trials, randomized controlled trials, and research conducted in humans. Additional information was obtained from the FDA website.

RESULTS: Three phase 3 trials are available for telaprevir, which provided data that were the basis for FDA approval. Boceprevir demonstrated efficacy and safety in 2 pivotal phase 3 trials. Both agents demonstrated statistically significantly higher rates of virologic response compared with the standard of care involving peginterferons and ribavirin. Telaprevir and boceprevir also demonstrated efficacy in the treatment of patients who had previously failed dual therapy for hepatitis $\mathrm{C}$. Safety concerns for both agents include anemia, drug interactions, skin rashes, and gastrointestinal adverse events.

CONCLUSIONS: Decision makers have many factors to consider in developing a strategy around hepatitis C. Increased drug costs, patient management, adherence, comparative safety and efficacy, and appropriate utilization management controls are important issues. Payers may consider developing clinical programs to encourage adherence and appropriate use and leverage an appropriate channel to ensure cost-effective therapy.

J Manag Care Pharm. 2011;17(9):685-94

Copyright $\odot 2011$, Academy of Managed Care Pharmacy. All rights reserved.

\section{What is already known about this subject}

- Historically, the standard of care for the treatment of hepatitis C has been pegylated interferon (peginterferon) and ribavirin.

- The protease inhibitors telaprevir and boceprevir were approved by the FDA in May 2011 for the treatment of hepatitis C genotype 1 in combination with peginterferon and ribavirin. Neither protease inhibitor may be used as monotherapy for hepatitis C.

\section{What this review adds}

- The current American Association for the Study of Liver Diseases (AASLD) Practice Guidelines (2011) recommend triple therapy with a protease inhibitor, peginterferon, and ribavirin as the standard treatment for hepatitis C.

- Both telaprevir and boceprevir have been studied in treatmentnaïve and previous partial responders, but only telaprevir has been studied in prior null responders.

- Managed care considerations of hepatitis C pertinent to decision makers include increased total drug treatment costs and potential increase in utilization, patient management and adherence, comparative safety and efficacy, and appropriate utilization management controls.

- The 12-week regimen of telaprevir therapy has a wholesale acquisition cost (WAC) in 2011 of $\$ 49,200$ (added to $\$ 17,175$ WAC for 24 weeks of peginterferon plus ribavirin [PR] or $\$ 34,349$ for 48 weeks of PR). The boceprevir WAC in 2011 is $\$ 26,410$ for the 24-week regimen (added to $\$ 20,037$ WAC for PR for 28 weeks, $\$ 25,762$ for 36 weeks, or $\$ 34,349$ for 48 weeks).

- Rates of anemia were $36 \%$ in the telaprevir-treated patents versus $17 \%$ for patients treated only with peginterferon and ribavirin. Anemia occurred in 45\%-50\% of boceprevir-treated patients versus $20 \%-30 \%$ of patients treated only with peginterferon and ribavirin; erythropoiesis-stimulating agents were used to manage anemia in $43 \%$ of boceprevir-treated patients versus $24 \%$ of patients treated only with peginterferon and ribavirin.

$\mathrm{H}$ epatitis $\mathrm{C}$ virus (HCV) is the most common chronic bloodborne illness in the United States. Approximately 3.9 million people in the United States have chronic infection. ${ }^{1} \mathrm{HCV}$ is a leading cause of liver transplant and liver cancer in the United States and worldwide. ${ }^{2,3}$ The incidence of acute hepatitis $C$ in the United States peaked near 50,000 cases in the late 1980s but has stabilized since 2003 to less than 5,000 cases annually. ${ }^{4}$ The progressive decline may be a result of increased education and public awareness of transmissible risk factors. ${ }^{4}$ Wong et al. (2000) estimated that direct medical expenditures for HCV would grow to $\$ 10.7$ billion over the 2010-2019 period despite a stable disease rate. ${ }^{5}$

$\mathrm{HCV}$ is transmitted by exposure to infected blood or blood products with injectable drug abuse being the leading cause. ${ }^{6}$ HCV has at least 6 genotypes and 50 different subtypes (i.e., HCV subtype $1 \mathrm{a}, 1 \mathrm{~b}$, etc.), with genotype 1 being the most 


\section{TABLE 1 FDA-Approved Indications, Dose, Administration, and Drug} Cost for Telaprevir and Boceprevir for HCV Infection

\begin{tabular}{|c|c|c|c|c|}
\hline Drug & Dose and Administration ${ }^{\mathrm{a}, \mathrm{b}}$ & FDA-Approved Indication ${ }^{a}$ & Peginterferon + Ribavirin & Drug Cost ${ }^{\mathrm{c}}$ \\
\hline $\begin{array}{l}\text { Telaprevir } \\
\text { (Incivek) } \\
375 \mathrm{mg} \\
\text { tablets }\end{array}$ & $\begin{array}{l}2 \text { tablets ( } 750 \mathrm{mg} \text { ) } 3 \text { times daily ( } 7-9 \text { hours apart) for } 12 \\
\text { weeks (all patients) } \\
\text { - "INCIVEK must be administered with both peginter- } \\
\text { feron alfa and ribavirin for all patients for } 12 \text { weeks, } \\
\text { followed by a response-guided regimen of either } 12 \text { or } \\
36 \text { additional weeks of peginterferon alfa and ribavirin } \\
\text { depending on viral response and prior response status." }\end{array}$ & $\begin{array}{l}\text { "In combination with peginterferon alfa and ribavirin, for } \\
\text { the treatment of genotype } 1 \text { chronic hepatitis C (CHC) in } \\
\text { adult patients with compensated liver disease, including } \\
\text { cirrhosis, who are treatment-naïve or who have been pre- } \\
\text { viously treated with interferon-based treatment, including } \\
\text { prior null responders, partial responders, and relapsers. } \\
\text { - INCIVEK must not be used as monotherapy and must } \\
\text { only be used in combination with peginterferon alfa and } \\
\text { ribavirin. } \\
\text { - A high proportion of previous null responders (particu- } \\
\text { larly those with cirrhosis) did not achieve SVR and had } \\
\text { telaprevir resistance-associated substitutions emerge on } \\
\text { treatment with INCIVEK. } \\
\text { - INCIVEK efficacy has not been established for patients } \\
\text { who have previously failed therapy with a treatment } \\
\text { regimen that includes INCIVEK or other HCV NS3/4A } \\
\text { protease inhibitors." }\end{array}$ & $\begin{array}{l}24 \text { weeks for undetect- } \\
\text { able HCV RNA at weeks } \\
4 \text { and } 12 \text { for treatment- } \\
\text { naïve and prior-relapse } \\
\text { patients } \\
48 \text { weeks for detectable } \\
\text { (1,000 IU per mL or } \\
\text { less) HCV RNA at weeks } \\
4 \text { and } 12 \text { for treatment- } \\
\text { naïve and prior-relapse } \\
\text { patients } \\
48 \text { weeks for undetect- } \\
\text { able HCV RNA at weeks } \\
4 \text { and } 12 \text { for treatment- } \\
\text { naive patients with } \\
\text { cirrhosis } \\
48 \text { weeks for all } \\
\text { prior-partial and null- } \\
\text { responder patients }\end{array}$ & $\begin{array}{l}\$ 49,200 \text { for } \\
12 \text { weeks } \\
\text { telaprevir } \\
\$ 17,175 \text { for } \\
24 \text { weeks PR } \\
\$ 34,349 \text { for } \\
48 \text { weeks PR }\end{array}$ \\
\hline \multirow[t]{2}{*}{$\begin{array}{l}\text { Boceprevir } \\
\text { (Victrelis) } \\
200 \mathrm{mg} \\
\text { capsules }\end{array}$} & $\begin{array}{l}\text { Initiate therapy with peginterferon alfa and ribavirin for } 4 \\
\text { weeks prior to starting boceprevir (lead-in phase) } \\
\text { At treatment week } 4 \text {, add boceprevir } 800 \mathrm{mg} \text { (four } 200 \mathrm{mg} \\
\text { capsules) orally } 3 \text { times daily (every } 7-9 \text { hours) with food } \\
\text { (a meal or light snack) } \\
\text { - "VICTRELIS must be administered in combination with } \\
\text { peginterferon alfa and ribavirin." } \\
24 \text { weeks for undetectable HCV RNA at weeks } 8 \text { and } 24 \\
\text { for treatment-naive patients } \\
32 \text { weeks for undetectable HCV RNA at weeks } 8 \text { and } 24 \\
\text { for prior-relapse and partial-responder patients } \\
32 \text { weeks for detectable ( }>9.3 \text { IU per mL) HCV RNA at } \\
\text { week } 8 \text { and undetectable at week } 24 \text { for treatment-naive, } \\
\text { prior-relapse and partial-responder patients }\end{array}$ & $\begin{array}{l}\text { "For the treatment of chronic hepatitis } \mathrm{C}(\mathrm{CHC}) \text { genotype } \\
1 \text { infection, in combination with peginterferon alfa and } \\
\text { ribavirin, in adult patients ( } \geq 18 \text { years of age) with com- } \\
\text { pensated liver disease, including cirrhosis, who are previ- } \\
\text { ously untreated or who have failed previous interferon } \\
\text { and ribavirin therapy." }\end{array}$ & $\begin{array}{l}28 \text { weeks for undetect- } \\
\text { able HCV RNA at weeks } \\
8 \text { and } 24 \text { for treatment- } \\
\text { naïve patients } \\
36 \text { weeks for undetect- } \\
\text { able HCV RNA at weeks } \\
8 \text { and } 24 \text { for prior- } \\
\text { relapse and partial- } \\
\text { responder patients } \\
48 \text { weeks for detectable } \\
\text { HCV RNA at week } 8 \text { and } \\
\text { undetectable at week } 24 \\
\text { for treatment-naive, pri- } \\
\text { or-relapse and partial- } \\
\text { responder patients }\end{array}$ & $\begin{array}{l}\$ 26,410 \text { for } \\
24 \text { weeks } \\
\text { boceprevir } \\
\$ 35,213 \text { for } \\
32 \text { weeks } \\
\text { boceprevir } \\
\$ 20,037 \text { for } \\
28 \text { weeks PR } \\
\$ 25,762 \text { for } \\
36 \text { weeks PR } \\
\$ 34,349 \text { for } \\
48 \text { weeks PR }\end{array}$ \\
\hline & $\begin{array}{l}\text { Patients with cirrhosis: } \\
4 \text { weeks peginterferon alfa and ribavirin (lead-in phase) } \\
\text { followed by } 44 \text { weeks boceprevir } 800 \mathrm{mg} \text { (four } 200 \mathrm{mg} \\
\text { capsules) } 3 \text { times daily (every } 7-9 \text { hours) in combination } \\
\text { with peginterferon alfa and ribavirin }\end{array}$ & Same as above & 48 weeks & $\begin{array}{l}\$ 48,418 \text { for } \\
44 \text { weeks } \\
\text { boceprevir } \\
\$ 34,349 \text { for } \\
48 \text { weeks PR }\end{array}$ \\
\hline
\end{tabular}

aSource: Product labels with prescribing information for telaprevir" ${ }^{11}$ and boceprevir. ${ }^{10}$

${ }^{b}$ Treatment duration for telaprevir depends on response.

'Cost estimates based on wholesale acquisition cost (WAC) price in September $2011 .{ }^{20} \mathrm{PR}$ regimen assumed peginterferon alfa-2a and ribavirin dosed at $1,200 \mathrm{mg}$ daily.

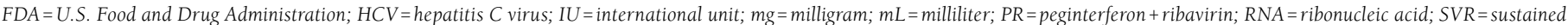
virologic response.

common in the United States. ${ }^{3}$ For every 100 people infected with HCV, 75-85 people will develop chronic infection; 60-70 will develop chronic liver disease; 5-20 will develop cirrhosis; and 1-5 will die of cirrhosis or liver cancer. ${ }^{7}$ Acute HCV illness manifests symptomatically in $20 \%-30 \%$ of patients. ${ }^{4}$ Possible symptoms include abdominal pain, fever, fatigue, loss of appetite, nausea, and vomiting. The remaining $70 \%-80 \%$ of patients may be asymptomatic or experience only mild symptoms. ${ }^{4}$

The American Association for the Study of Liver Diseases (AASLD) Practice Guidelines (2011) represent the gold standard for guidance on the management of hepatitis C. ${ }^{6}$ These guidelines were approved and are supported by the AASLD, the Infectious Diseases Society of America, and the American College of Gastroenterology. ${ }^{6}$ The combination of pegylated interferon (peginterferon) and ribavirin has been the standard recommended treatment for $\mathrm{HCV}$ prior to the release of the protease inhibitors. ${ }^{6}$

Telaprevir and boceprevir were approved by the U.S. Food and Drug Administration (FDA) in May 2011 in combination with peginterferon alfa and ribavirin for the treatment of genotype 1 chronic hepatitis $C$ in adult patients with compensated liver disease, including cirrhosis, who are treatment-naïve or who have been previously treated with interferon-based treatment (Table 1). ${ }^{8,9}$ Both agents inhibit the NS3/4A serine protease essential for replication of $\mathrm{HCV} \cdot{ }^{10,11}$ The introduction of the protease inhibitors, or directly acting antivirals, significantly changes the landscape of HCV management for both treatmentnaive and treatment-experienced patients. 


\section{FIGURE 1 Flowchart of Literature Selection}

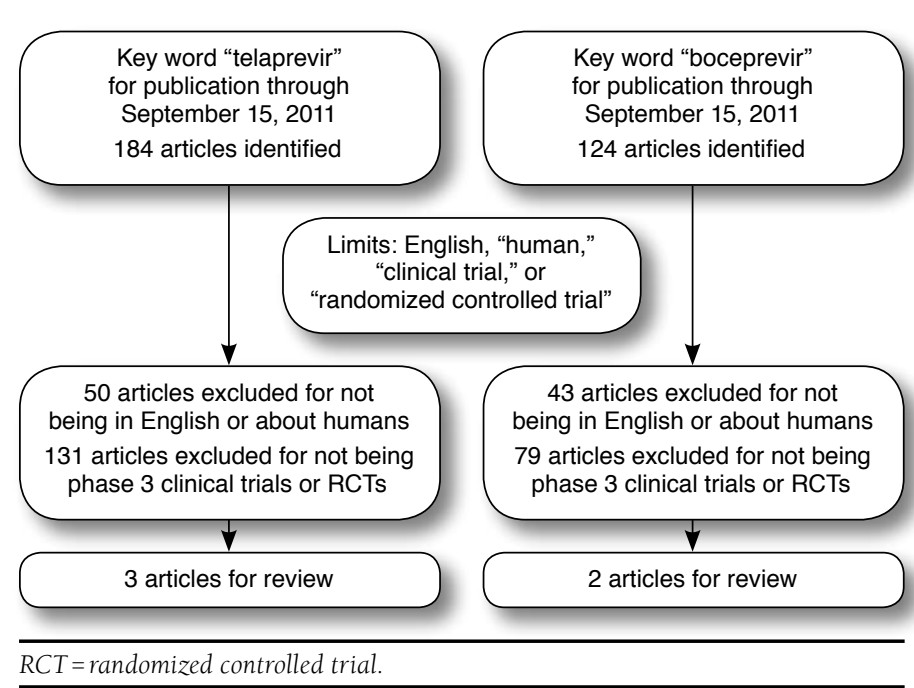

The purpose of this article is to (a) provide an overview of the clinical data for telaprevir and boceprevir, including the pharmacokinetics, phase 3 pivotal trial efficacy, and safety; and (b) offer insight to managed care decision makers on management strategies for HCV based on factors that include clinical data, cost, need for adherence, and coverage determination.

\section{Search Method and Results}

A MEDLINE review was performed for articles published and available through September 15, 2011, using keywords "telaprevir" and "boceprevir" with an emphasis on published randomized controlled trials (Figure 1). The literature search was limited to articles in English, clinical trials, randomized controlled trials, and research conducted in humans; review articles and meta-analyses were excluded. Additional information was obtained from the FDA website.

\section{Pharmacokinetics}

Telaprevir. Telaprevir is bioavailable and absorbed in the small intestine. ${ }^{12}$ For optimal exposure, telaprevir must be taken with food (not low fat). Systemic exposure (area under the curve [AUC]) is increased by $237 \%$ in conjunction with a standard fat meal (533 kilocalories and 21 grams fat) compared with the fasted state. When co-administered with peginterferon, maximum concentration at steady state $\left(C_{\text {max,ss }}\right)$ and AUC are increased by $43 \%$ and $38 \%$, respectively. Ribavirin does not affect telaprevir plasma concentrations, and maximum plasma concentrations are reached in 4 to 5 hours after a dose..$^{13}$ In vitro studies have shown telaprevir to be a substrate and inhibitor of P-glycoprotein (P-gp) and CYP3A, resulting in clinically significant drug interactions (see Table 2). ${ }^{13}$ Telaprevir is 59\%

\section{TABLE 2 Safety Warnings for} Telaprevir and Boceprevir

\begin{tabular}{l|l|l|l|l}
\hline Drug & \multicolumn{1}{|c|}{$\begin{array}{c}\text { Label } \\
\text { Warnings }\end{array}$} & $\begin{array}{l}\text { Other Adverse } \\
\text { Reactions }\end{array}$ & $\begin{array}{l}\text { Contraindicated } \\
\text { Medications } \\
\text { Specific to } \\
\text { Telaprevir or } \\
\text { Boceprevir }\end{array}$ & $\begin{array}{l}\text { Contraindicated } \\
\text { Medications } \\
\text { for Both } \\
\text { Telaprevir and } \\
\text { Boceprevir }\end{array}$ \\
\hline $\begin{array}{l}\text { Telaprevir } \\
\text { (Incivek) }^{11}\end{array}$ & $\begin{array}{l}\text { Serious skin } \\
\text { reactions (drug } \\
\text { rash with } \\
\text { eosinophilia } \\
\text { and systemic } \\
\text { symptoms, } \\
\text { Stevens-Johnson } \\
\text { Syndrome), rash, } \\
\text { anemia }\end{array}$ & $\begin{array}{l}\text { Hemorrhoids, } \\
\text { anorectal } \\
\text { discomfort, } \\
\text { anal pruritus, } \\
\text { dysgeusia, } \\
\text { fatigue, } \\
\text { pruritus, } \\
\text { nausea, } \\
\text { diarrhea }\end{array}$ & atorvastatin & $\begin{array}{l}\text { alfuzosin, } \\
\text { rifampin, dihy- } \\
\text { droergotamine, } \\
\text { ergonovine, } \\
\text { ergotamine, } \\
\text { methylergono- } \\
\text { vine, cisapride, } \\
\text { St. John's Wort, } \\
\text { lovastatin, } \\
\text { simvastatin, } \\
\text { pimozide, silde- } \\
\text { nafil, tadalafil, } \\
\text { triazolam, oral } \\
\text { midazolam }\end{array}$ \\
\hline $\begin{array}{l}\text { Boceprevir } \\
\text { (Victrelis) }^{10}\end{array}$ & $\begin{array}{l}\text { Anemia, } \\
\text { neutropenia }\end{array}$ & $\begin{array}{l}\text { Fatigue, } \\
\text { nausea, } \\
\text { headache, } \\
\text { dysgeusia }\end{array}$ & $\begin{array}{l}\text { carbamaze- } \\
\text { pine, phe- } \\
\text { nobarbital, } \\
\text { phenytoin, } \\
\text { drosperinone }\end{array}$ & \\
\hline
\end{tabular}

to $76 \%$ bound to plasma proteins (alpha-1-acid glycoprotein and albumin).

In the phase 2 studies PROVE 2 and PROVE 3, a population pharmacokinetic analysis was performed using pharmacokinetic data from all subjects. After oral administration, the apparent total clearance was about 31.6 liters (L) per hour and $37.5 \mathrm{~L}$ per hour in PROVE 2 and PROVE 3, respectively. ${ }^{13}$ Telaprevir undergoes hepatic metabolism, and primary route of elimination is fecal. Elimination half-life is 4 to 4.7 hours.

Boceprevir. Boceprevir should be taken with food, but type of meal and timing are not crucial. Clinical trials demonstrated boceprevir AUC increased up to $65 \%$ when taken with food. ${ }^{14}$ Boceprevir reaches maximum plasma concentration 3 hours after a dose. An in vitro study showed boceprevir to be a P-gp substrate..$^{14,10}$ Boceprevir is also a CYP3A4/5 substrate and strong inhibitor and is approximately $75 \%$ plasma protein bound (see Table 2 for clinically significant drug interactions). ${ }^{14}$

In vitro studies showed boceprevir to be primarily metabolized through the aldoketoreductase (AKR)-mediated pathway to ketone-reduced metabolites (inactive). Mean apparent clearance of boceprevir is $157 \mathrm{~L}$ per hour, and its elimination halflife is approximately 3.4 hours. The primary route of elimination is fecal.

\section{Efficacy and Safety}

Telaprevir. The efficacy and safety of telaprevir was studied in three phase 3 pivotal trials: ADVANCE (Telaprevir for Previously Untreated Chronic Hepatitis C Virus Infection), ${ }^{15}$ ILLUMINATE (Response-Guided Telaprevir Combination Treatment for Hepatitis C Virus Infection), ${ }^{16}$ and REALIZE (Telaprevir for Retreatment of HCV Infection). ${ }^{17}$ The study designs, samples, and efficacy and safety outcomes are shown in Table 3. 
Formulary Management of the Protease Inhibitors Boceprevir and Telaprevir for Chronic Hepatitis C Virus

\section{TABLE 3 Efficacy and Safety Results from Phase 3 Trials of Telaprevir}

Study/Drug Regimens ADVANCE $^{15}$

T12PR: Triple therapy (telaprevir with peginterferon alfa-2a plus ribavirin [PR]) for 12 weeks

- After the first 12 weeks, patients with extended RVR ${ }^{d}$ received 12 additional weeks of PR alone (total treatment duration 24 weeks)

- Patients lacking extended RVR ${ }^{\mathrm{d}}$ received 36 additional weeks of PR alone (total treatment duration 48 weeks)

T8PR: Triple therapy for 8 weeks followed by placebo plus PR for 4 weeks

- After the first 12 weeks, patients with extended RVR ${ }^{\mathrm{d}}$ received 12 additional weeks of PR alone (total treatment duration 24 weeks)

- Patients lacking extended RVR ${ }^{\mathrm{d}}$ received 36 additional weeks of PR alone (total reatment duration 48 weeks)

PR: Placebo plus PR for 12 weeks followed by PR alone for an additional 36 weeks (total treatment duration 48 weeks)

The following doses were used:

- telaprevir $750 \mathrm{mg}$ orally every 8 hours with food

- peginterferon alfa-2a 180 mcg subcutaneously weekly

- ribavirin 1,000 mg orally daily (patients weighing $<75 \mathrm{~kg}$ ) or ribavirin $1,200 \mathrm{mg}$ orally daily (patients weighing $\geq 75 \mathrm{~kg}$ ) Therapy was stopped if HCV RNA levels were $>1,000 \mathrm{IU}$ per $\mathrm{mL}$ at week 4 (T12PR and T8PR groups; only telaprevir discontinued); $<2 \log _{10}$ decrease from baseline in HCV RNA levels occurred at week 12 (discontinue all drugs); or had detectable HCV RNA at any time between weeks 24 and 40 (discontinue all drugs).

ILLUMINATE ${ }^{16}$

T12PR24: Triple therapy (telaprevir plus PR) for 12 weeks, followed by PR alone for 12 weeks (total treatment duration 24 weeks)

T12PR48: Triple therapy for 12 weeks, followed by PR alone for 36 weeks (total treatment duration $=48$ weeks)

The following doses were used:

- telaprevir $750 \mathrm{mg}$ orally with food every 8 hours

- peginterferon alfa-2a $180 \mathrm{mcg}$ subcutaneously weekly

- ribavirin 1,000 mg orally daily (patients weighing $<75 \mathrm{~kg}$ ) or ribavirin $1,200 \mathrm{mg}$ orally daily (patients weighing $\geq 75 \mathrm{~kg}$ ) Therapy was stopped if HCV RNA levels were $>1,000$ IU per $\mathrm{mL}$ at week 4 (only telaprevir discontinued); $<2 \log _{10}$ decrease in HCV RNA from baseline occurred at week 12 ; or had detectable HCV RNA between weeks 24 and 36 .
Design/Sample

Phase 3, double-blind, placebo-

controlled RCT

\section{Inclusion Criteria}

- 18 to 70 years of age

- HCV genotype 1 infection with evidence of chronic hepatitis, as confirmed by means of a liver biopsy within 1 year before screening for the study (including patients with compensated liver cirrhosis)

- Seronegativity for hepatitis B surface antigen and the absence of antibodies against human immunodeficiency virus types 1 and 2

- Absolute neutrophil counts at least 1,500 per $\mathrm{mm}^{3}$

- Platelet counts at least 90,000 per mm

- Hemoglobin levels at least $12 \mathrm{gm}$ per dL for women or at least $13 \mathrm{gm}$ per $\mathrm{dL}$ for men

\section{Exclusion Criteria}

- Decompensated liver disease

- Liver disease from other causes

- Hepatocellular carcinoma

Baseline Characteristics

- Well balanced between treatment groups

- $58 \%$ male, $9 \%$ black, $11 \%$ Hispanic

- $21 \%$ bridging fibrosis or cirrhosis

- $59 \%$ HCV subtype la

- $40 \%$ HCV subtype $1 b$

- $1 \%$ HCV subtype unknown

- Average HCV RNA ( $\log _{10}$ IU per mL): 6.3 in all groups

- $77 \%$ with HCV RNA $\geq 800,000$ IU per $\mathrm{mL}$

Phase 3, open-label, randomized, noninferiority trial. Results of HCV RNA testing were double-blinded through week 24 Inclusion Criteria

- Age between 18 and 70 years

- Presence of chronic infection with HCV genotype 1, indicated by diagnosis at more than 6 months before the screening visit, with a detectable HCV RNA level at the visit, as well as no previous treatment for HCV infection

- Seronegative test for hepatitis B virus and human immunodeficiency virus

- Absolute neutrophil count of 1,500 or more per $\mathrm{mm}^{3}$

- Platelet count of 90,000 or more per mm

- Hemoglobin level of 12 gm or more per dL for female patients or $13 \mathrm{gm}$ or more per dL for male patients

- Liver biopsy within 1 year before screening visit or under went the procedure during the screening period unless a biopsy more than 1 year previously showed evidence of cirrhosis

Exclusion Criteria

- Hepatic decompensation

- Clinically significant liver disease from another cause

- Active cancer within the previous 5 years (except treated basal-cell carcinoma)

Baseline Characteristics

- Well balanced between treatment groups

- $60 \%$ male, $14 \%$ black, $10 \%$ Hispanic or Latino

- $16 \%$ bridging fibrosis

- $72 \%$ HCV subtype la

- $27 \%$ HCV subtype $1 b$

- $1 \%$ HCV subtype unknown

- $79 \%$ with HCV RNA $\geq 800,000$ IU per $\mathrm{mL}$
Results

\begin{tabular}{|c|c|c|c|c|}
\hline Treatment Group & T12PR & T8PR & PR & $\begin{array}{c}P \text { Value } \\
\text { Versus PR }\end{array}$ \\
\hline & $\mathrm{n}=363$ & $\mathrm{n}=364$ & $\mathrm{n}=361$ & \\
\hline \multicolumn{5}{|c|}{ Efficacy outcomes, \% (n) } \\
\hline $\mathrm{SVR}^{\mathrm{a}}$ at 24 weeks & $75(271)$ & $69(250)$ & $44(158)$ & $<0.001$ \\
\hline $\begin{array}{l}\text { Undetectable }{ }^{\mathrm{b}} \mathrm{HCV} \\
\text { RNA at } 72 \text { weeks }\end{array}$ & $73(265)$ & $67(243)$ & $44(158)$ & - \\
\hline $\mathrm{RVR}^{\mathrm{c}}$ & $68(246)$ & $66(242)$ & $9(34)$ & - \\
\hline Extended RVR $^{\mathrm{d}}$ & $58(212)$ & $57(207)$ & $8(29)$ & - \\
\hline Relapse $^{e}$ & $6(17)$ & $7(18)$ & $27(51)$ & - \\
\hline \multicolumn{5}{|c|}{ Safety outcomes, \% (n) } \\
\hline Rash $^{\mathrm{f}}$ & $37(133)$ & 35 (129) & $24(88)$ & - \\
\hline DC due to rash & $7(24)$ & $5(17)$ & $1(2)$ & - \\
\hline Anemiag $^{\mathrm{g}}$ & $37(135)$ & $39(141)$ & $19(70)$ & - \\
\hline DC due to AEs & $10(36)$ & $10(37)$ & $7(26)$ & - \\
\hline
\end{tabular}

"Sustained virologic response. Undetectable (lower limit of detection 10 IU per $m L$ ) plasma HCV RNA 24 weeks after the last planned study dose of patient's assigned treatment. Primary endpoint.

${ }^{b}$ Lower limit of detection $10 \mathrm{IU}$ per $\mathrm{mL}$

Rapid virologic response, defined as undetectable HCV RNA at week

Undetectable HCV RNA at weeks 4 and 12

'Undetectable HCV RNA levels at the end of the treatment period, but confirmed detectable HCV RNA levels some time between the end of treatment and 24 weeks after last study dose.

Rash was eczematous and reversed by discontinuing telaprevir. Stevens-Johnson syndrome occurred in 1 patient about 11 weeks after completing telaprevir treatment.

${ }^{g} H e m o g l o b i n ~ l e v e l ~<10 \mathrm{gm}$ per $d L$ : ESAs were not used to manage anemia; the ribavirin dose was reduced in accordance with product labeling (the efficacy of the regimen is not compromised if ribavirin is reduced; ribavirin concentrations achieved are similar to that of full dosing in a nonanemic patient). $D C=$ discontinuation

\begin{tabular}{|l|c|c|}
\hline Treatment Group & $\begin{array}{c}\text { Randomly } \\
\text { Assigned to } \\
\text { T12PR24 }\end{array}$ & $\begin{array}{c}\text { Randomly } \\
\text { Assigned to } \\
\text { T12PR48 }\end{array}$ \\
\hline & $\mathrm{n}=162$ & $\mathrm{n}=160$ \\
\hline
\end{tabular}

Efficacy outcomes, \% (n)

\begin{tabular}{|l|c|c}
\hline SVR $^{a}$ at 24 weeks & $92(149)$ & $88(140)$ \\
\hline RVR $^{\mathrm{b}}$ & $100(162)$ & $99(159)$ \\
\hline Extended RVR $^{c}$ & $100(162)$ & $99(159)$ \\
\hline Relapse $^{\mathrm{d}}$ & $6(9)$ & $3(4)$
\end{tabular}

Safety outcomes, \% (n)

Rash

DC due to rash

Anemia $^{e}$

DC due to AEs

${ }^{a}$ Sustained virologic response. Undetectable (lower limit of detection

approximately 10 to $15 \mathrm{IU}$ per $\mathrm{mL}$ ) plasma HCV RNA level at end of treatment phase and 24 weeks after the last planned study dose. Primary endpoint. Overall, $72 \%(n=540)$ of enrolled patients achieved SVR

${ }^{b}$ Undetectable HCV RNA level at week 4.

'Undetectable HCV RNA level at week 4 and week 12

${ }^{d}$ Undetectable HCV RNA at end of treatment, but detectable after the end of treatment.

'Determined by investigators' opinion. ESAs were not used to manage anemia; the ribavirin dose was reduced in accordance with product labeling (the efficacy of the regimen is not compromised if ribavirin is reduced; ribavirin concentrations achieved are similar to that of full dosing in a nonanemic patient).

$D C=$ discontinuation 
Formulary Management of the Protease Inhibitors Boceprevir and Telaprevir for Chronic Hepatitis C Virus

\section{TABLE 3 Efficacy and Safety Results from Phase 3 Trials of Telaprevir (continued)}

Study/Drug Regimens REALIZE $^{17}$

T12PR48: Triple therapy (telaprevir plus PR) for 12 weeks, followed by placebo plus PR for 4 weeks, and then PR alone for 32 weeks (total treatment duration 48 weeks)

Lead-in T12PR48: Placebo plus PR for 4 weeks, followed by triple therapy for 12 weeks and then PR alone for 32 weeks (total treatment duration $=48$ weeks)

PR48 (control): Placebo plus PR for 16 weeks, followed by PR for 32 weeks (total treatment duration $=48$ weeks)

The following doses were used:

- telaprevir $750 \mathrm{mg}$ orally every 8 hours

- peginterferon alfa-2a 180 mcg subcutaneously weekly

- ribavirin $1,000 \mathrm{mg}$ orally daily or 1,200

mg orally daily (weight based)

Patients were stratified by baseline viral load (HCV RNA $<800,000$ or $\geq 800,000$ IU per $\mathrm{mL}$ ) and type of previous response to peginterferon-ribavirin (no response, partial response, or relapse)

Therapy was stopped if HCV RNA levels were $>100$ IU per $\mathrm{mL}$ at weeks 4,6 , and 8 after start of telaprevir treatment (T12PR48 and lead-in T12PR48 groups; only telaprevi discontinued) $<2 \log _{10}$ decrease from baseline in HCV RNA levels occurred at week 12 (T12PR48 group and control groups) or week 16 (lead-in T12PR48 group); or had detectable HCV RNA at week 24 or 36.

\begin{tabular}{|c|c|c|c|c|c|}
\hline \multirow{2}{*}{$\begin{array}{l}\text { Design/Sample } \\
\begin{array}{l}\text { Phase } 3 \text { double blind, } \\
\text { placebo-controlled RCT }\end{array}\end{array}$} & \multicolumn{5}{|c|}{ Results } \\
\hline & Treatment Group & T12PR48 & $\begin{array}{l}\text { Lead-in } \\
\text { T12PR48 }\end{array}$ & PR48 & $\begin{array}{c}P \text { Value } \\
\text { Versus PR48 }\end{array}$ \\
\hline \multirow{10}{*}{$\begin{array}{l}\text { Inclusion Criteria } \\
\text { - } 18 \text { to } 70 \text { years of age } \\
\text { - Chronic HCV genotype } 1 \text { infection } \\
\text { - Did not have a SVR to } 1 \text { previous } \\
\text { course of PR despite receiving at } \\
\text { least } 80 \% \text { of the intended dose } \\
\text { - Detectable HCV RNA } \\
\text { - Liver biopsy within } 18 \text { months } \\
\text { before screening } \\
\text { - Absolute neutrophil count } \geq 1,200 \\
\text { per } \mathrm{mm}^{3} \\
\text { - Platelet count } \geq 90,000 \text { per } \mathrm{mm}^{3} \\
\text { - Hemoglobin levels at least } 12 \mathrm{gm} \\
\text { per dL for women or at least } 13 \mathrm{gm} \\
\text { per dL for men }\end{array}$} & & $\mathrm{n}=266$ & $\mathrm{n}=264$ & $n=132$ & \\
\hline & \multicolumn{5}{|l|}{$S V^{a}$ at 24 weeks, $\%(n)$} \\
\hline & Previous relapse $^{\mathrm{b}}$ & $83(121 / 145)$ & $88(124 / 141)$ & $24(16 / 68)$ & $<0.001$ \\
\hline & $\begin{array}{l}\text { No response or partial } \\
\text { response to previous therapy }\end{array}$ & $41(50 / 121)$ & $41(51 / 123)$ & $9(6 / 64)$ & $<0.001$ \\
\hline & Previous partial response $e^{c}$ & $59(29 / 49)$ & $54(26 / 48)$ & $15(4 / 27)$ & $<0.001$ \\
\hline & No previous response $^{\mathrm{d}}$ & $29(21 / 72)$ & $33(25 / 75)$ & $5(2 / 37)$ & $<0.001$ \\
\hline & All patients & 64 & 66 & 17 & $<0.001$ \\
\hline & \multicolumn{5}{|l|}{ Relapse, ${ }^{\text {b } \% ~(n) ~}$} \\
\hline & Previous relapse & $7(10 / 135)$ & $7(9 / 138)$ & $65(30 / 46)$ & - \\
\hline & $\begin{array}{l}\text { Lack previous } \\
\text { virologic response }\end{array}$ & - & - & - & - \\
\hline \multirow{4}{*}{$\begin{array}{l}\text { Exclusion Criteria } \\
\text { - Decompensated liver disease } \\
\text { - Liver disease from other causes } \\
\text { - Hepatocellular carcinoma }\end{array}$} & Previous partial response & $21(8 / 39)$ & $25(9 / 36)$ & 0 & - \\
\hline & No previous response & $27(8 / 30)$ & $25(9 / 36)$ & $60(3 / 5)$ & - \\
\hline & \multicolumn{5}{|c|}{ Safety outcomes: all patients, \% (n) } \\
\hline & Rash & $37(99)$ & $36(95)$ & $19(25)$ & - \\
\hline \multirow{4}{*}{$\begin{array}{l}\text { Baseline Characteristics } \\
\text { - Well balanced between treatment } \\
\text { groups } \\
\text { - } 70 \% \text { male, } 5 \% \text { black, } 11 \% \text { Hispanic } \\
\text { - } 26 \% \text { cirrhosis } \\
\text { - } 53 \% \text { previous relapse } \\
\text { - } 19 \% \text { partial response } \\
\text { - } 28 \% \text { no response } \\
\text { - } 45 \% \text { HCV subtype la } \\
\text { - } 45 \% \text { HCV subtype lb } \\
\text { - HCV subtype unknown (1 patient) } \\
\text { - Average baseline HCV RNA (log } 10 \\
\text { IU per mL): } 6.6 \text { in all groups } \\
\text { - } 88.5 \% \text { with HCV RNA } \geq 800,000 \\
\text { IU per mL }\end{array}$} & DC due to rash & $5(12)$ & $4(10)$ & 0 & - \\
\hline & Anemia $^{e}$ & $30(79)$ & $36(94)$ & $15(20)$ & - \\
\hline & DC due to AEs & $15(39)$ & $11(29)$ & $3(4)$ & - \\
\hline & \multicolumn{5}{|c|}{$\begin{array}{l}\text { aSVR is the primary endpoint defined as undetectable (lower limit of detection } 10 \mathrm{IU} \text { per mL) } \\
\text { HCV RNA } 24 \text { weeks after last planned study dose. } \\
{ }^{b} \text { Undetectable HCV RNA at the end of a previous course of therapy with HCV RNA positivity } \\
\text { thereafter. } \\
\text { a2 } \log _{10} \text { decrease in HCV RNA after } 12 \text { weeks of therapy but with detectable HCV RNA. } \\
\text { d<2 } \log _{10} \text { decrease in HCV RNA after } 12 \text { weeks of therapy. } \\
\text { 'Determined by investigators' opinion. ESAs were not used to manage anemia; the ribavirin dose } \\
\text { was reduced in accordance with product labeling (the efficacy of the regimen is not compromised } \\
\text { if ribavirin is reduced; ribavirin concentrations achieved are similar to that of full dosing in a } \\
\text { nonanemic patient). } \\
\text { DC= discontinuation. }\end{array}$} \\
\hline
\end{tabular}

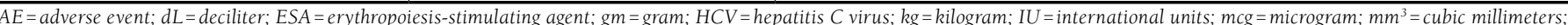
$P R=$ peginterferon+ribavirin; $R C T=$ randomized controlled trial; $R N A=$ ribonucleic acid; $R V R=$ rapid virologic response; $S V R=$ sustained virologic response.

Boceprevir. The efficacy and safety of boceprevir was studied in two phase 3 pivotal trials: SPRINT-2 (Boceprevir for Untreated Chronic HCV Genotype 1 Infection) and RESPOND-2 (Boceprevir for Previously Treated Chronic HCV Genotype 1 Infection). The study designs, samples, and efficacy and safety outcomes are shown in Table 4.

\section{Managed Care Considerations}

The arrival of the protease inhibitors has had a significant impact on the management of genotype 1 hepatitis C. Both agents have demonstrated significantly improved sustained virologic response (SVR) rates compared with conventional dual therapy with peginterferon and ribavirin. However, both protease inhibitors introduce issues that managed care decision makers will need to address in order to optimize cost-effective use. Decision makers need to consider increased total drug treatment costs, patient management and adherence, comparative safety and efficacy, and appropriate utilization management controls when deciding on a strategy for hepatitis $\mathrm{C}$ treatment.
Head-to-head comparative clinical trials are lacking between telaprevir and boceprevir. Both agents have studies in treatment-naïve and previous partial responders, but only telaprevir has been studied in prior null responders. ${ }^{17}$ AASLD guidelines recommend the use of telaprevir for prior null responders. ${ }^{6}$ Although both agents were studied with peginterferon, telaprevir was used with peginterferon alfa-2a while boceprevir trials used peginterferon alfa- $2 \mathrm{~b}$. There may be speculation that the overall efficacy of the protease inhibitors could be affected by choice of peginterferon because there are efficacy differences between peginterferon alfa- $2 \mathrm{a}$ and $\mathrm{alfa}-2 \mathrm{~b}$ in the hepatitis $\mathrm{C}$ population. Some payers may require the use of one specific peginterferon in a utilization management program, regardless of the protease inhibitor used. Current literature and FDA labeling for the protease inhibitors does not support the use of one distinct peginterferon product over the other. The rationale for peginterferon preferred product selection by a payer could be multifaceted, including product cost, manufacturer discounts, channel steerage, and clinical differences.

In cross-trial comparisons, telaprevir appears to have a 
Formulary Management of the Protease Inhibitors Boceprevir and Telaprevir for Chronic Hepatitis C Virus

\section{TABLE 4 Efficacy and Safety Results from Phase 3 Trials of Boceprevir}

Study/Drug Regimens

\section{SPRINT-2 ${ }^{18}$}

Control: PR for 4 weeks (lead-in period), followed by placebo plus PR for 44 weeks (total treatment duration 48 weeks)

Response-guided: PR for 4 weeks (lead-in period) followed by boceprevir plus PR for 24 weeks

- Patients would end therapy if HCV levels were undetectable (lower limit of detection 9.3 IU per $\mathrm{mL}$ ) from week 8 through 24 (total treatment duration 28 weeks)

- Otherwise, patients received placebo plus PR for an additional 20 weeks (total treatment duration 48 weeks)

Fixed duration: PR for 4 weeks (lead-in period), followed by boceprevir plus PR for 44 weeks (total treatment duration $=48$ weeks)

The following doses were used:

- boceprevir $800 \mathrm{mg}$ orally 3 times daily with food

- peginterferon alfa-2b 1.5 mcg per kg subcutaneously weekly

- ribavirin weight-based dosing 600 to $1,400 \mathrm{mg}$ orally daily in divided doses in morning and evening

Patients were enrolled separately into 2 cohorts: blacks and nonblacks, due to differences in SVR between the groups. They were stratified by genotype 1 subtype (a or b) and HCV RNA level $(\leq 400,000$ IU per $\mathrm{mL}$ or $>400,000$ IU per $\mathrm{mL})$.

Patients discontinued treatment if they had a detectable HCV RNA level at week 24.

\section{RESPOND-2 ${ }^{19}$}

Control: PR for 4 weeks (lead-in period), followed by placebo with PR for 44 weeks (total treatment duration 48 weeks)

Response-guided: PR for 4 weeks (lead-in period) followed by boceprevir with PR for 32 weeks

- Patients would end therapy if HCV RNA levels were undetectable (lower limit of detection 9.3 IU per $\mathrm{mL}$ ) at week 8 and 12 (total treatment duration 36 weeks)

- Patients with a detectable level at week 8 but undetectable at week 12 received PR for an additional 12 weeks (total treatment duration 48 weeks)

Fixed duration: PR for 4 weeks (lead-in period), followed by boceprevir with PR for 44 weeks (total treatment duration $=48$ weeks)

The following doses were used:

- boceprevir $800 \mathrm{mg}$ orally 3 times daily with food

- peginterferon alfa-2b 1.5 mcg per kg subcutaneously weekly

- ribavirin weight-based dosing 600 to $1,400 \mathrm{mg}$ orally daily in divided doses at morning and evening

Patients were stratified by previous response to therapy (nonresponse or relapse) and HCV subtype (la or lb). Nonresponse was defined as a decrease in the HCV RNA level at least $2 \log _{10}$ IU per mL by week 12 but with a detectable level during therapy period. Relapse was defined as undetectable (lower limit of detection 9.3 IU per mL) HCV RNA level at the end of treatment, but detectable levels during follow-up.

Patients discontinued all treatment if they had a detectable HCV RNA level at week 12 .
Design/Sample

Phase 3 placebo-controlled RCT

Inclusion Criteria

- 18 years of age or older

- Chronic infection with HCV

genotype 1 with no previous

history of HCV treatment

- Plasma HCV RNA level

$\geq 10,000$ IU per mL

- Weight 40 to $125 \mathrm{~kg}$

Exclusion Criteria

- Liver disease not related to

hepatitis C

- Decompensated cirrhosis

- Renal insufficiency

- HIV or hepatitis B infection

- Pregnancy or current breastfeeding

- Active cancer

Baseline Characteristics

- Well balanced between treatment groups

- $60 \%$ male, $14 \%$ black, $82 \%$ white, $4 \%$ other

- $64 \%$ HCV subtype la

- $33 \%$ HCV subtype lb

- $3 \%$ HCV subtype unknown

- $85 \%$ with HCV RNA > 800,000 IU per $\mathrm{mL}$

Phase 3 placebo-controlled RCT

Inclusion Criteria

- 18 years of age or older

- Chronic infection with HCV genotype 1 and prior response to interferon (minimum

12-week duration of therapy)

- Plasma HCV level $\geq 10,000$ IU per $\mathrm{mL}$

- Weight 40 to $125 \mathrm{~kg}$

Exclusion Criteria

- Hepatitis B or infection with

human immunodeficiency virus

- Liver disease not related to

hepatitis C

- Decompensated liver disease

- Uncontrolled diabetes mellitus

- Severe psychiatric disorder

- Active substance abuse

Baseline Characteristics

- $67 \%$ male, $12 \%$ black, $86 \%$

white, $2 \%$ other

- $47 \%$ HCV subtype la

- $44 \%$ HCV subtype $1 b$

- $9 \%$ HCV subtype unknown

- $12 \%$ cirrhosi

- $88 \%$ with HCV RNA > 800,000 IU per $\mathrm{mL}$
Results

\begin{tabular}{|c|c|c|c|c|}
\hline Treatment Group & Control & $\begin{array}{l}\text { Response- } \\
\text { Guided }\end{array}$ & $\begin{array}{l}\text { Fixed } \\
\text { Duration }\end{array}$ & $\begin{array}{l}P \text { Value } \\
\text { Versus } \\
\text { Control }\end{array}$ \\
\hline & $n=363$ & $\mathrm{n}=368$ & $\mathrm{n}=366$ & \\
\hline \multicolumn{5}{|l|}{ SVR $^{a}$ at 24 weeks, \% (n) } \\
\hline All patients & $38(137)$ & $63(233)$ & $66(242)$ & $<0.001$ \\
\hline Nonblack cohort & $40(125 / 311)$ & $67(211 / 316)$ & $68(213 / 311)$ & $<0.001$ \\
\hline Black cohort & $23(12 / 52)$ & $42(22 / 52)$ & $53(29 / 55)$ & $0.040 ; 0.004$ \\
\hline \multicolumn{5}{|l|}{ Relapse $^{\text {b }}, \%$ (n) } \\
\hline All patients & $22(39 / 176)$ & $9(24 / 257)$ & $9(24 / 265)$ & $<0.001$ \\
\hline \multicolumn{5}{|c|}{ Safety outcomes: all patients, \% (n) } \\
\hline Anemia $^{c}$ & $29(107)$ & $49(182)$ & $49(179)$ & $<0.001$ \\
\hline ESA use & $24(87)$ & $43(159)$ & $43(159)$ & $<0.001$ \\
\hline $\begin{array}{l}\text { Mean duration of } \\
\text { ESA in days }\end{array}$ & 121 & 94 & 156 & - \\
\hline DC due to anemia & $1.1(4)$ & $1.6(6)$ & $1.9(7)$ & - \\
\hline $\begin{array}{l}\text { Neutrophil count } 500 \text { to } \\
<750 \text { per } \mathrm{mm}^{3} \text { (grade } 3 \text { ) }\end{array}$ & $14(50)$ & $24(87)$ & $25(90)$ & $<0.001$ \\
\hline Dysguesia & $18(64)$ & $37(137)$ & $43(156)$ & $<0.001$ \\
\hline DC due to AEs & $16(57)$ & $12(45)$ & $16(60)$ & - \\
\hline
\end{tabular}

${ }^{a} S V R$ is the primary endpoint defined as undetectable (lower limit of detection 9.3 IU per $m L)$ HCV RNA levels for 24 weeks after completing therapy.

${ }^{b}$ Detectable HCV RNA levels during follow-up despite undetectable levels at the end of treatment.

'Hemoglobin $<10 \mathrm{gm}$ per dL. Ribavirin dose was reduced or ESA administered at the discretion of investigators (the efficacy of the regimen is not compromised if ribavirin is reduced; ribavirin concentrations achieved are similar to that of full dosing in a nonanemic patient). $D C=$ discontinuation

\begin{tabular}{|c|c|c|c|c|}
\hline Treatment Group & Control & $\begin{array}{l}\text { Response- } \\
\text { Guided }\end{array}$ & $\begin{array}{l}\text { Fixed } \\
\text { Duration }\end{array}$ & $\begin{array}{l}P \text { Value } \\
\text { Versus } \\
\text { Control }\end{array}$ \\
\hline & $\mathrm{n}=80$ & $\mathrm{n}=162$ & $\mathrm{n}=161$ & \\
\hline \multicolumn{5}{|l|}{ Efficacy outcomes, \% (n) } \\
\hline$S_{V R}{ }^{a}$ at 24 weeks & $21(17)$ & $59(95)$ & $66(107)$ & $<0.001$ \\
\hline Early response $\mathrm{e}^{\mathrm{b}}$ & $9(7)$ & $46(74)$ & $52(84)$ & - \\
\hline SVR among early responders & $100(7 / 7)$ & $86(64 / 74)$ & $88(74 / 84)$ & - \\
\hline Relapse $^{c}$ & $31(25)$ & $15(17)$ & $12(14)$ & - \\
\hline \multicolumn{5}{|l|}{ Safety outcomes, \% (n) } \\
\hline Anemia $^{\mathrm{d}}$ & $20(16)$ & $43(70)$ & $46(74)$ & $<0.001$ \\
\hline ESA use $^{e}$ & $21(17)$ & $41(66)$ & $46(74)$ & $0.003 ;<0.001$ \\
\hline DC due to anemia & 0 & 0 & $3(5)$ & - \\
\hline $\begin{array}{l}\text { Neutrophil count } 500 \text { to } \\
<750 \text { per } \mathrm{mm}^{3} \text { (grade } 3 \text { ) }\end{array}$ & $9(7)$ & $19(30)$ & $20(32)$ & $0.060 ; 0.030$ \\
\hline Dysgeusia & $11(9)$ & $43(69)$ & $45(72)$ & $<0.001$ \\
\hline DC due to AEs & $2(2)$ & $8(13)$ & $12(20)$ & $0.150 ; 0.020$ \\
\hline
\end{tabular}

aPrimary endpoint defined as a undetectable (lower limit of detection $9.3 \mathrm{IU}$ per $\mathrm{mL}$ ) HCV RNA levels at week 24 after completing therapy.

${ }^{b}$ Undetectable HCV RNA level at week 8 .

'Undetectable HCV RNA level at the end of treatment, but detectable levels during follow-up. ${ }^{d H e m o g l o b i n ~ l e v e l ~}<10 \mathrm{gm}$ per $\mathrm{dL}$. Ribavirin dose was reduced or an ESA administered at the discretion of investigators. Efficacy of the regimen is not compromised if ribavirin is reduced; ribavirin concentrations achieved are similar to that of full dosing in a nonanemic patient.

${ }^{e}$ A total of 16 patients who received ESA also received a red blood-cell transfusion.

$D C=$ discontinuation 
significantly elevated risk of rash compared with boceprevir ( $22 \%$ vs. $2 \%$ in previously untreated patients). ${ }^{10,11}$ StevensJohnson syndrome occurred in 1 patient about 11 weeks after completing telaprevir treatment. ${ }^{15}$ Anemia appeared to occur at similar rates with telaprevir and boceprevir in cross-trial comparisons (19\% vs. $20 \%$ in previously untreated patients). ${ }^{10,11}$ Although anemia was managed differently in the clinical trials (telaprevir patients received ribavirin dose/frequency modifications, and boceprevir patients received erythropoiesis-stimulating agents [ESAs]), practitioners will likely consider the use of ESAs with either protease inhibitor depending on their own clinical experience with these agents. ${ }^{15,17-19}$ Managed care payers may include provisions in utilization management programs that manage anemia in patients receiving either of the protease inhibitors with ribavirin dose reduction (efficacy of the regimen is not compromised if the ribavirin dose is reduced; ribavirin concentrations achieved will be similar to that of full dosing in a nonanemic patient) and allow the use of ESAs at particular hemoglobin levels if ribavirin dose reduction is insufficient to manage anemia. Comparative trials and studies in different patient subgroups, including those with human immunodeficiency virus (HIV) coinfection, are needed to fully understand the differences between the protease inhibitors.

\section{Drug Cost}

Telaprevir and boceprevir will bring substantial new pharmacy costs to the management of hepatitis $C$. The wholesale acquisition cost (WAC) of telaprevir is $\$ 97.62$ per 375 milligram (mg) tablet and $\$ 13.10$ per $200 \mathrm{mg}$ tablet of boceprevir. ${ }^{20}$ Full treatment costs will vary considerably depending on treatment duration, drug choice, and patient mix. Based on WAC pricing, the cost of 12 weeks of telaprevir would be $\$ 49,200.48$, and boceprevir WAC would range from $\$ 26,409.60$ for 24 weeks to $\$ 48,417.60$ for 44 weeks of therapy, in addition to the costs for peginterferon plus ribavirin (Table 1). Telaprevir's higher cost may be balanced by the significantly easier dosing regimen of telaprevir (12 weeks in all cases) versus the more confusing, response-guided boceprevir regimen.

Additional costs will be incurred in the management of adverse effects from the oral agents. Anemia managed by ESAs would add significant cost to the regimen versus management via ribavirin dose reduction. Rates of anemia were 36\% in the telaprevir-treated patients versus $17 \%$ for patients treated only with peginterferon and ribavirin. ${ }^{11}$ Anemia occurred in $45 \%-50 \%$ of boceprevir-treated patients versus $20 \%-30 \%$ of patients treated only with peginterferon and ribavirin..$^{10}$ In the SPRINT-2 trial, anemia with boceprevir was managed via ESA 40,000 units administered weekly, with a mean duration of 94 weeks of ESA therapy in the response-guided group and 156 weeks in the fixed-duration group versus 121 weeks in the peginterferon-ribavirin group. ${ }^{18}$ Forty-three percent of boceprevir-treated patients received ESAs compared with
$24 \%$ of patients receiving only peginterferon plus ribavirin in clinical trials. ${ }^{10}$ The WAC of a vial of 40,000 units of ESA is $\$ 679.00 .{ }^{20}$ Depending on the duration of therapy, ESAs could add significantly to the total costs of the regimens of the protease inhibitors. Laboratory monitoring and clinic visits may also be increased as patients are monitored for response and adherence.

Prior to the approval of the protease inhibitors, McAdamMarx et al. (2011) found that average total all-cause costs were $\$ 19,665$ per patient per year (PPPY) in 2009 dollars for HCVinfected patients. ${ }^{21}$ The cost of HCV management will more than double or triple for patients with genotype 1 infection treated with triple therapy. Additionally, WAC pricing does not account for mark-ups in pharmacy provider channels or drug manufacturer rebates. Due to the increased costs, payers should strongly consider implementation of utilization and care management programs that help ensure that the right patients receive the appropriate therapy and are adherent to therapy.

\section{Utilization Management}

A clinically focused, comprehensive utilization management program is imperative in the management of hepatitis $C$. The utilization management criteria should include the following factors: appropriate patient selection, concomitant therapy, safety considerations, dosing, and continuation of therapy. Appropriate patient selection may exclude groups not studied in phase 3 trials with the oral protease inhibitors, including viral genotypes other than 1 and individuals with HIV coinfection. In these groups, treatment with the standard dual therapy may be applicable. Concomitant therapy with peginterferon and ribavirin is critical to the success of protease inhibitor therapy. Utilization management programs may be used to mandate triple therapy in patients with genotype 1 infection unless they have contraindications to the protease inhibitors. A utilization management program should also ensure appropriate dosing of protease inhibitors and peginterferon as well as approval of therapy durations limited to what is necessary to complete treatment. Both telaprevir and boceprevir have numerous contraindications and serious drug interactions. Coverage criteria should consider screening for these situations prior to approving therapy. Finally, both protease inhibitors have guidelines regarding treatment futility (Figure 2). These criteria predict treatment failures based on viral loads at specific time points. Management programs may include these stopping points verbatim to ensure patients are being monitored and responding to therapy. However, if managed care decision makers decide to follow the futility rules, 2 points must be considered. First, coverage approvals should extend beyond required laboratory checks to allow for reporting of viral loads without the patient running out of medication. Second, meeting the futility rules should stop coverage of both the protease inhibitor and the peginterferon. 
FIGURE 2 Hepatitis C Treatment Algorithm: Telaprevir ${ }^{\mathrm{a}}$ and Boceprevir ${ }^{\mathrm{b}}$

\section{Telaprevir}

Futility Rules

Week 12

HCV RNA level $\geq 1,000$ IU per $\mathrm{mL}$

DISCONTINUE ALL THERAPY

Week 4

HCV RNA level $\geq 1,000$ IU per $\mathrm{mL}$

DISCONTINUE ALL THERAPY

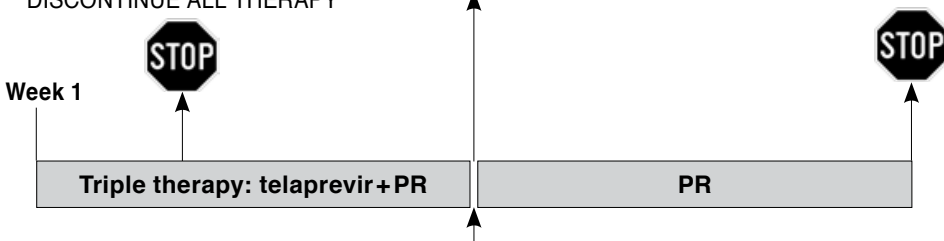

Discontinue telaprevir

Continuation Rules

Treatment-naïve* and prior-relapse patients:

Week 24

Week 48

Not detectable at week 4 and week 12-continue PR through week 24

*for patients with cirrhosis-continue PR

through week 48 unless detectable at week 24

Detectable at week 4 and/or week 12 - continue PR through week 48 unless detectable at week 24

Prior partial- and null-responder patients:

Week 48

Not detectable at week 4 and week 12-continue PR through week 48 unless detectable at week 24

\section{Boceprevir}

Futility Rules
Week 12

HCV RNA level $\geq 100$ IU per $\mathrm{mL}$ DISCONTINUE ALL THERAPY

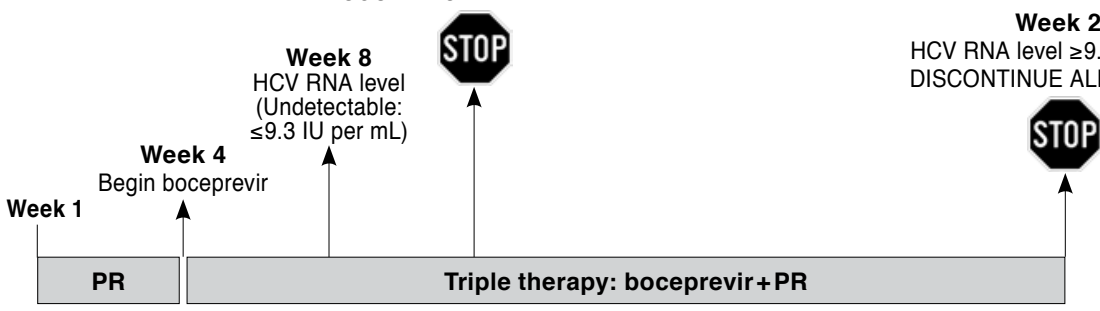

Continuation Rules

Treatment-naïve patients:

Week 28

Not detectable at week 8 and week 24-continue

triple therapy with boceprevir +PR through week 28

Detectable at week 8 and not detectable at week 12-complete boceprevir at week 36 and continue PR through week 48

Prior-relapse and partial-responder patients:

Week 36

Not detectable at week 4 and week 24-continue triple therapy with boceprevir+PR through week 36

Detectable at week 8 and not detectable at week 12-complete boceprevir at week 36 and continue PR through week 48

Patients with cirrhosis:

4 weeks of PR followed by 44 weeks of triple therapy with boceprevir+PR 
Patient adherence is crucial to the cost-effective use of the protease inhibitors in hepatitis $\mathrm{C}$. Nonadherent patients are at significant risk of treatment failure and resistance development. ${ }^{22}$ Managed care decision makers may implement a care management program in conjunction with utilization management criteria to ensure patients are monitored for appropriate use and adherence to therapy. Many specialty pharmacies have experience in care management of hepatitis C. Ideally, a care management program would include regular (weekly or monthly) calls from a pharmacist to the patient to assess current adherence to therapy. Prescription claims could also be monitored to ensure consistent filling, and a call could be placed to members suspected of having a gap in care. Payers may consider limiting distribution of hepatitis C treatments to a specialty pharmacy that offers comprehensive care management to patients. Finally, managed care decision makers should educate the specialty pharmacy and practitioners on the specifics of the utilization management criteria, which will reduce potentially duplicative efforts by the payer and the specialty pharmacy in care requirements, such as laboratory tests, or potentially inconsistent periods for approved duration of therapy. Provider education could be delivered via training modules and/or having a subject matter expert available to answer questions on the criteria.

The release of telaprevir and boceprevir marks a unique event in which 2 disease-changing therapies received FDA approval within days of each other. Such events provide payers with the opportunity to gather information and data on how new therapies are adopted, alter existing utilization of established therapies, and impact medical and pharmacy costs. Prime Therapeutics reported that the utilization of drugs for hepatitis C decreased by $22.1 \%$ in 2010 compared with 2009 , contributing to a $15.2 \%$ decrease in drug cost for these drugs ( $-\$ 0.03$ per member per month), $9 \%$ of which was in medical benefit costs and $91 \%$ was in pharmacy benefit costs. ${ }^{23}$ Although pharmacy costs will increase with the use of the protease inhibitors, the total cost of caring for patients with hepatitic $C$ infection should decrease due to the increased cure rates with the protease inhibitors. The release of the protease inhibitors will cause the first surge in use of hepatitis $C$ agents as treatment-naïve and previously treated patients attempt therapy. Payers should gather data on the changes in utilization and how the different products perform (e.g., use of prescription claims to determine utilization trend, cost per claim after applicable discounts, and medical claims information to monitor for adverse events such as anemia). This information could prove useful in determining the value that the market places on different aspects of competing drugs including dosing, safety profile, cost, and effectiveness of utilization management tools. Additionally, comprehensive data collection could further define the true cost of the 2 agents when taking into consideration discounts, channel, and adverse events.

\section{Conclusions}

With FDA approval of the new protease inhibitors, decision makers have many factors to consider in developing a strategy around hepatitis C. Increased drug costs, patient management, adherence, comparative safety and efficacy, and appropriate utilization management controls are important issues. Despite the great advancement in hepatitis $C$ treatment, the protease inhibitors have a significant adverse effect profile and pill burden. An appropriate utilization management strategy should be implemented to ensure patients receive optimal benefit from therapy.

\section{Authors}

ALEXANDRA TUNGOL, PharmD, is Pharmacy Resident; KELLIE RADEMACHER, PharmD, is Senior Clinical Pharmacist; and JEREMY A. SCHAFER, PharmD, MBA, is Senior Director of Utilization Management, Prime Therapeutics LLC, Eagan, Minnesota.

AUTHOR CORRESPONDENCE: Jeremy A. Schafer, PharmD, MBA, Prime Therapeutics LLC, 1305 Corporate Center Dr., Eagan, MN 55121. Tel.: 612.777.5097; Fax: 612.777.5143; E-mail: jschafer@primetherapeutics.com.

\section{DISCLOSURES}

There was no external funding for this manuscript. The authors are employees of Prime Therapeutics LLC, a pharmacy benefits management company whose ownership includes health plans.

Concept and design were performed by Tungol and Schafer. Data collection and interpretation were performed primarily by Tungol with the assistance of Rademacher and Schafer. The manuscript was written primarily by Tungol and Schafer and revised primarily by Tungol and Rademacher.

\section{REFERENCES}

1. Colvin HM, Mitchell AE, eds. Committee on the Prevention and Control of Viral Hepatitis Infections. Hepatitis and Liver Cancer: A National Strategy for Prevention and Control of Hepatitis B and C. Washington, DC: Institute of Medicine, The National Academies Press; 2010. Available at: http://www. nap.edu/catalog.php?record_id=12793. Accessed October 28. 2011.

2. European Association for the Study of the Liver. EASL Clinical Practice Guidelines: management of hepatitis $C$ virus infection. Journal of Hepatology. 2011;55(2):245-64. Available at: http://www.easl.eu/assets/application/ files/4a7bd873f9cccbf_file.pdf. Accessed October 28, 2011.

3. U.S. Centers for Disease Control. Hepatitis $C$ information for health professionals. March 14, 2011. Available at: http://www.cdc.gov/hepatitis/HCV/ index.htm. Accessed October 28, 2011.

4. Ferguson M. Current therapies for chronic hepatitis C. Pharmacotherapy. 2011;31(1):92-111

5. Wong JB, McQuillan GM, McHutchison JG, Poynard T. Estimating future hepatitis C morbidity, mortality, and costs in the United States. Am J Public Health. 2000;90(10):1562-69. Available at: http://www.ncbi.nlm.nih.gov/ pmc/articles/PMC1446368/?tool=pubmed. Accessed October 28, 2011. 
6. Ghany MG, Nelson DR, Strader DB, Thomas DL, Seeff LB. An update on treatment of genotype 1 chronic hepatitis $C$ virus infection: 2011 practice guideline by the American Association for the Study of Liver Diseases. Hepatology. 2011;54(4):1433-44.

7. U.S. Centers for Disease Control. Hepatitis C. June 2010. Available at: http://www.cdc.gov/hepatitis/HCV/PDFs/HepCGeneralFactSheet.pdf. Accessed October 28. 2011.

8. U.S. Food and Drug Administration. FDA news release. FDA approves Incivek for hepatitis C. May 23, 2011. Available at: http://www.fda.gov/ NewsEvents/Newsroom/PressAnnouncements/ucm256299.htm. Accessed October 28, 2011.

9. U.S. Food and Drug Administration. FDA news release. FDA approves Victrelis for hepatitis C. May 13, 2011. Available at: http://www.fda.gov/ NewsEvents/Newsroom/PressAnnouncements/ucm255390.htm. Accessed October 28, 2011.

10. Victrelis (boceprevir) capsules. Merck. May 2011. Available at: http:// www.accessdata.fda.gov/drugsatfda_docs/label/2011/202258lbl.pdf. Accessed October 28, 2011.

11. Incivek (telaprevir) film coated tablets. Vertex. May 2011. Available at: http://www.accessdata.fda.gov/drugsatfda_docs/label/2011/201917lbl.pdf. Accessed October 28, 2011.

12. Perni RB, Almquist SJ, Byrn RA, et al. Preclinical profile of VX-950, a potent, selective, and orally bioavailable inhibitor of hepatitis $C$ virus NS3-4A serine protease. Antimicrob Agents Chemother. 2006;50(3):899-909. Available at: http://dl2af5jf3e.search.serialssolutions.com/?sid=Entrez:PubMe d\&id=pmid:16495249. Accessed October 28, 2011.

13. U.S. Food and Drug Administration. Center for Drug Evaluation and Research. Clinical pharmacology and biopharmaceutics review of telaprevir. Application number 201917. July 8, 2011. Available at: http://www.accessdata.fda.gov/drugsatfda_docs/nda/2011/201917Origls000ClinPharmR.pdf. Accessed October 28, 2011.

14. U.S. Food and Drug Administration. Center for Drug Evaluation and Research. Clinical pharmacology and biopharmaceutics review of boceprevir. Application number 20225. June 14, 2011. Available at: http://www. accessdata.fda.gov/drugsatfda_docs/nda/2011/2022580rigls000ClinPhar mR.pdf. Accessed October 28, 2011.
15. Jacobson IM, McHutchison JG, Dusheiko G, et al., for the ADVANCE Study Team. Telaprevir for previously untreated chronic hepatitis $C$ virus infection. N Engl J Med. 2011;364(25):2405-16. Available at: http://www. nejm.org/doi/full/10.1056/NEJMoal012912. Accessed October 28, 2011.

16. Sherman KE, Flamm SL, Afdhal NH, et al., for the ILLUMINATE Study Team. Response-guided telaprevir combination treatment for hepatitis C virus infection. N Engl J Med. 2011;365(11):1014-24. Available at: http:// www.nejm.org/doi/full/10.1056/NEJMoal014463. Accessed October 28, 2011.

17. Zeuzem S, Andreone P, Pol S, et al., for the REALIZE Study Team. Telaprevir for retreatment of HCV infection. N Engl J Med. 2011; 364(25):2417-28. Available at: http://www.nejm.org/doi/full/10.1056/ NEJMoal013086. Accessed October 28, 2011.

18. Poordad F, McCone J Jr, Bacon BR, et al., for the SPRINT-2 Investigators. Boceprevir for untreated chronic HCV genotype 1 infection. N Engl J Med. 2011;364(13):1195-206. Available at: http://www.nejm.org/doi/full/10.1056/ NEJMoal010494. Accessed October 28, 2011.

19. Bacon BR, Gordon SC, Lawitz E, et al., for the RESPOND-2 Investigators. Boceprevir for previously treated chronic HCV genotype 1 infection. N Engl J Med. 2011;364(13):1207-17. Available at: http://www.nejm.org/doi/ full/10.1056/NEJMoa1009482. Accessed October 28, 2011.

20. Wolters Kluwer Health. Medi-Span Master Drug Data Base v2.5 (MDDB). Accessed September 20, 2011.

21. McAdam-Marx C, McGarry LJ, Hane CA, Biskupiak J, Deniz B, Brixner DI. All-cause and incremental per patient per year cost associated with chronic hepatitis $C$ virus and associated liver complications in the United States: a managed care perspective. J Manag Care Pharm. 2011;17(7):53146. Available at: http://www.amcp.org/WorkArea/DownloadAsset. aspx?id=10710.

22. Lo Re V 3rd, Teal V, Localio AR, Amorosa VK, Kaplan DE, Gross R. Relationship between adherence to hepatitis $C$ virus therapy and virologic outcomes: a cohort study. Ann Intern Med. 2011;155(6):353-60.

23. Prime Therapeutics. 2011 Drug Trend Insights. August 2011. Available at: http://www.primetherapeutics.com/PDF/2011PrimeDrugTrendInsights. pdf. Accessed October 28, 2011. 